\title{
A case report on inVALUABLE: insect value chain in a circular bioeconomy
}

Heckmann, L.-H.; Andersen, J.L.; Eilenberg, J.; Fynbo, J.; Miklos, R.; Nygaard Jensen, Annette ; Nørgaard, J. V.; Roos, N.

Published in:

Journal of Insects as Food and Feed

Link to article, DOI:

10.3920/JIFF2018.0009

Publication date:

2019

Document Version

Early version, also known as pre-print

Link back to DTU Orbit

Citation $(A P A)$ :

Heckmann, L-H., Andersen, J. L., Eilenberg, J., Fynbo, J., Miklos, R., Nygaard Jensen, A., Nørgaard, J. V., \& Roos, N. (2019). A case report on inVALUABBLE: insect value chain in a circular bioeconomy. Journal of Insects as Food and Feed, 5(1), 9-13. https://doi.org/10.3920/JIFF2018.0009

\section{General rights}

Copyright and moral rights for the publications made accessible in the public portal are retained by the authors and/or other copyright owners and it is a condition of accessing publications that users recognise and abide by the legal requirements associated with these rights.

- Users may download and print one copy of any publication from the public portal for the purpose of private study or research.

- You may not further distribute the material or use it for any profit-making activity or commercial gain

- You may freely distribute the URL identifying the publication in the public portal 


\section{inVALUABLE: Insect Value Chain in a Circular Bioeconomy}

Lars-Henrik Heckmann ${ }^{1,}{ }^{*}$, Jonas Lembcke Andersen ${ }^{1}$, Jørgen Eilenberg ${ }^{2}$, Jens Fynbo ${ }^{3}$, Rikke Miklos ${ }^{4}$, Annette Nygaard Jensen ${ }^{5}$, Jan Værum Nørgaard ${ }^{6}$, Nanna Roos ${ }^{7}$

1 Danish Technological Institute, Life Science, Aarhus, Denmark

2 University of Copenhagen, Department of Plant and Environmental Sciences, Copenhagen, Denmark

3 Hannemann Engineering, Sønderborg, Denmark

4 Danish Technological Institute, AgroTech, Aarhus, Denmark

5 Technical University of Denmark, National Food Institute, Lyngby, Denmark

6 Aarhus University, Department of Animal Science, Foulum, Denmark

7 University of Copenhagen, Department of Nutrition, Exercise and Sports, Copenhagen, Denmark

*Corresponding author

\section{Abstract}

To date, inVALUABLE is among the largest publicly-funded R\&D effort on insects as feed and food in the EU. The vision of inVALUABLE is to create a sustainable resource-efficient industry for animal production based on insects. inVALUABLE has focus on the R\&D demand for scaling up production of insects and assessing the application potential of particularly mealworms. The inVALUABLE consortium partners span the entire value chain and include entrepreneurs, experts in biology, biotechnology, automation, processing and food tech and -safety. This paper provides an overview of the goal, partners and activities performed during the first year of the project.

\section{Introduction}

Insects constitute a new agri-business with great potential as climate- and resource-efficient production of animal protein. Compared to conventional terrestrial livestock, the immediate advantages of insects include: i) superior feed conversion efficiency; ii) low water usage, low landuse and low emission of greenhouse gases for producing the same level of protein; iii) possibility of using by-products as insect diet including biomasses currently utilized for energy production; full utilization of insect biomass as feed/food; and v) high nutritional value of the product and low risk of foodborne zoonotic pathogens (Huis et al., 2013).

In Europe, insect production is becoming a strategic business area with attention from numerous small and medium enterprises as well as large corporations within the feed and food sector. Yet, it is still a new business area in Denmark and the rest of the EU. The insect sector is gradually moving from a pre-commercial (R\&D-dominated) to a commercial level, but there are only a few established large-scale producers scattered throughout the EU; and from a food sector perspective none have yet reached an industrial level regarding output (e.g. 1,000+ ton insect biomass per year). 
Denmark may prove an excellent base for exploring the potential of insects as feed and food. In Denmark, approximately 5,000 pig farms produce approx. 28 million pigs annually.

The Danish knowledge base on animal farming, and pigs in particular, is very strong in relation to other EU member states.

Over the last five years, the knowledge institution partners of inVALUABLE have been involved in over 15 international and national R\&D projects (with cumulative total budget of $>10$ million EUR) on insects as feed and food; covering various topics of relevance throughout the insect value chain focusing on feed and food application, for example; development of mealworm feed (Heckmann et al., in press), optimization of mealworm reproduction (Berggreen et al., in press) as well as assessment of metabolic performance (Bjørge et al., in press), insect diseases (Eilenberg et al., 2015), environmental impact (Halloran et al., 2017), nutritional value (Kinyuru et al., 2013), consumer acceptance (Homann et al., 2017) and feed safety (Nordentoft et al., 2017).

This paper provides an overview of the goal, partners and activities carried out during the course of the project to date. The majority of the project is still to be conducted and results will be reported and published continuously.

\section{inVALUABLE in brief}

The project runs from January 2017 to December 2019 and has a total budget of 3.7M EUR with an investment of 2.5M EUR from Innovation Fund Denmark. At this point in time inVALUABLE is the largest R\&D project in Europe on insects as feed and food. The vision of inVALUABLE is to create a sustainable resource-efficient industry for animal protein production based on insects. Overall, inVALUABLE addresses three major challenges for the insect industry; 1 ) upscaling of production to industrial level, 2) regulatory issues and 3) consumer acceptance. The latter is approached through strong focus on communication regarding external stakeholder management as well as dissemination of project activities at different public and professional events. inVALUABLE had over 25 events during 2017 in both Denmark and internationally, e.g. Insecta 2017 (www.insectaconference.com) and Insectinov2 (www.adebiotech.org/ins2/en.ins2.php).

The goal is that inVALUABLE will facilitate the emerging Danish and European industrial insect production and be an enabler of new market opportunities for insects as feed, food and other highvalue components. inVALUABLE aims to demonstrate the potential of using insects to meet the 
increasing demand for protein in the food chain by assessing the following specific objectives: 1) developing an insect value chain using low-value by-products - reintroducing valuable resources back into the food chain; 2) document the nutritional potential of insects using state-of-the-art animal models; 3 ) combine the best technologies to enable market penetration, focusing on large-scale production, automation and processing; and 4) support Danish/EU authorities on feed/food legislation providing data to ensure safe insect products.

\section{inVALUABLE consortium}

inVALUABLE involves 10 partners that span the entire value chain and include entrepreneurs, experts in biology (entomology and nutrition), biotechnology, automation, processing and food tech and -safety. This interaction of competences is key to lifting insect production to an industrial level. Table 1 provides an overview of the different partners follow by an individual description below.

Table 1. Overview of consortium partners

\begin{tabular}{|l|l|}
\hline Institutions & Companies \\
\hline Danish Technological Institute (DTI) & Novozymes (NZ) \\
Aarhus University (AU) & Hannemann Engineering (HME) \\
University of Copenhagen (UCPH) & Ausumgaard (AG) \\
Technical University of Denmark (DTU) & ScrapTrans (ST) \\
& Agro Korn (AK) \\
& DryingMate (DM) \\
\hline
\end{tabular}

Danish Technological Institute (DTI) is a self-owned not-for-profit organization with the primary aim to apply and disseminate research- and technology-based knowledge for different industries. DTI has strategic focus on R\&D and business development within bioeconomy. DTI has built an integrated innovation chain across divisions with a portfolio covering commercial activities and several R\&D projects on insect production, focusing on black solider flies and mealworms (e.g. Berggreen et al., in press), as well as development of processing and various insect-based products for feed and food. The Department of Animal Science, Research Centre Foulum at Aarhus University (AU) has facilities and competences to carry out a broad range of research in animal nutrition and physiology. Special focus is on animal production, which is sustainable regarding both production economy and environment. $\mathrm{AU}$ is likewise active in research on the effects of insects on vertebrate immunology (e.g. Józefiak \& Engberg, 2017); and has worked with insects as animal feed since 2012 together with 
DTI and DTU (see below) in the BIOCONVAL project (www.icrofs.dk/en/research/danishresearch/organic-rdd-1/bioconval/).

University of Copenhagen (UCPH) is joining with three research groups from three departments: Insect Pathology and Biological Control (IPBC), Paediatric and International Nutrition (PIN), and Nordic Food Lab (NFL). These groups have all established research within the overall field of insects as food and feed, covering insect diseases (e.g. Eilenberg et al., 2017A and B), human nutrition and food innovation. The inVALUABLE project contributes to further strengthening the emerging UCPH research capacity on insects for food and feed. IPBC aims at establishing a service for diagnosing insect diseases for the upcoming EU insect industry - a service that will be further developed in the project. PIN has established research expertise on the nutritional value of insects as food as well as broader perspectives of insects as a novel sustainable protein source, and lead the research project GREEiNSECT (www.greeinsect.ku.dk) in Kenya. NFL have for years been working at creating a cultural shift towards insects as a viable food source in Denmark and Europe, and expect that eating insects will not be stigmatized at the end of the project.

The National Food Institute, Technical University of Denmark (DTU) has extensive experience in studying transmission of zoonotic pathogens from farm to fork (e.g. Nordentoft et al., 2017); and function as National Reference Laboratory for microbiological and chemical hazards incl. foodborne pathogens and antimicrobial resistance. DTU has for many years worked closely together with the Danish Veterinary and Food Administration and European Food Safety Authorities (EFSA) aiming to provide science-based knowledge as basis for their decisions. Experts from UCPH and DTU were members of the working group that generated the EFSA risk opinion on insects as feed and food (EFSA Scientific Committee, 2015).

Novozymes (NZ) is a world leader in industrial enzyme production and microbial solutions with main R\&D facilities and headquarters located in Denmark. Novozymes is innovation driven and constantly surveying novel areas with promising futures; including the potential of insects with regards to applications in feed and food enzymes.

Hannemann Engineering (HME) is a small mechanical engineering company dealing with complete action and automation solutions for different industries. Their core competencies include mechanical design in 3D, customized design and development and sourcing functions. HME have been part of providing automated solutions for insect production since 2015 , e.g. in collaboration with DTI and Proti-Farm in the SUSMEAL project (www.dti.dk/projects/project-sustainablemealworm-production-for-feed-and-food/38305?cms.query=susmeal) (e.g. Heckmann et al., in press). 
Ausumgaard (AG) is a large Danish estate with a strong belief in a future for agriculture that includes insect production. AG has a mission to be part of the future insect industry and contributes with experience from livestock on a large scale, but can aid the anchoring of knowledge and experience in Danish agriculture.

ScrapTrans (ST) is specialized in buying by-products from feed and food companies and reutilizing these for animal feed (mainly pig feed). Since 2014, ScrapTrans have been partners in two smaller projects, e.g. VALIN (www.dti.dk/projects/project-insects-convert-food-residue-into-valuablefeed/38306?cms.query=valin\%A8) about insect production using collected by-products. ST have good insight into by-products, and modern facilities for pre-processing these into suitable feeding substrates for insect production.

Agro Korn A/S (AK) focus on developing value added feed ingredients with different functionalities for a range of market segments including e.g. pet food, fish, poultry, pigs and young ruminants. AK has a vision to create the future protein- and feed ingredients and wish to be far-sighted and adjust to future demands.

DryingMate $A / S$ (DM) develops and sells customized and energy-efficient drying systems for the industry; and has over 15 years of experience with development and production of drying systems for feed and food. DM's drying processes are characterized by high safety, high product quality, low operating costs and no dust or odour emissions.

\section{Project activities}

inVALUABLE is coordinated by DTI, it operates at an applied research level and is organized in three focal areas - Production, Processing and Product Application. Production focuses on optimization of the production of mealworms; improving the understanding of mealworm health and nutrition; and development of innovative technologies for implementing cost-effective production systems through automation and monitoring of mealworm health. The processing area will develop processing methods of feeding substrates and insect biomass using different established and new technologies. Also, it will assess the feed/food safety of the obtained mealworm products as well as regulatory advocacy with relevant stakeholders. Product Application focuses on how mealworm can be applied in feed and food products. Also, we will assess and document the nutritional and health value of such products by the use of state-of-the-art animal models; including the recommended assessment method 'DIAAS' (digestible indispensable amino acid score) for protein digestibility. Food application of mealworms will be considered including focus on sensory of insect-based products; and finally, we aim at influencing the market and public perception of insects as food through a diverse dissemination strategy including focus on consumer acceptance. 


\section{Production}

Optimizing and increasing mealworm production using Yellow mealworm (Tenebrio molitor) is one of the main activities. There is emphasis on increasing the knowledge about egg output and a reducing variation in size and density in the production trays. This includes development of diets for adult beetles that increase reproduction and developing an assay to assess several key parameters such as adult female's viable time, fecundity and hatchability of the eggs - adding knowledge to previous work conducted at DTI (e.g. Berggreen et al., in press). Additionally, optimal production conditions regarding temperature, humidity and larvae density will be determined at lab- and pilot-scale, using the pilot factory facilities constructed at DTI early in the project.

By improving the understanding of the nutritional needs of mealworms, we can boost future yields, prevent insect diseases, and design insect-based products for feed/food that among other things contain desirable amino or fatty acids. Selected by-products will be investigated to assess their nutritional value as feeding substrate for mealworms. This will be supplemented by an assessment of substrate suitability (e.g. volume, price, availability and safety).

Activities on nutrition and health aims at improving the understanding of the nutritional needs of mealworms and assess the feed potential of a range of selected by-products. Moreover, there will be a strong focus on preventing and/or managing mealworm diseases (insect pathogenic fungi, bacteria, protozoa, virus etc.), for example, by identification of key probiotic bacteria. Scientific assessment will be carried out to investigate how different diets, as prebiotics, influence immune system-related traits in mealworms. For instance, probiotic bacteria with antimicrobial properties will be screened in vitro for their activity against selected insect pathogens. Moreover, mealworm bioassays will be conducted on promising prebiotic diets as well as selected diets including probiotics to assess in vivo effects of pre- and probiotic treatments on mealworm resistance and tolerance towards pathogens.

Automation of production focuses on designing "second generation" automation and monitoring systems, and selected proto-types that can be implemented in pilot-production. In order to reduce manual labour, innovative technologies will be implemented to achieve a cost-effective production system through improved mechanization and automation, including digitalized monitoring of mealworm health. The objective is to design a cost-effective automated system for rearing mealworms based on data-exchange to integrate an adaptive process control of the system (Industry 
4.0). A selection of relevant prototypes (e.g. either for monitoring or handling operations) will be implemented in at least one of the planned pilot production facilities.

\section{Processing}

The development of processing will determine the best available technologies for processing feeding substrates and insect biomass for feed and food. The processing of mealworms by novel drying technologies will be applied, and the processed mealworms will later be tested on rats, poultry and pigs. Processing is important to ensure the development of a high-quality protein meal as raw material for application in various feed and food products. The activities will focus on the development of processing of feeding substrates and insect biomass using different established and new technologies, e.g. drying, milling and extrusion. Product specification and performance will be evaluated on the processed insect biomass. Moreover, we will use a 'value logistics tool' based on the modification of an existing biomass supply chain tool to evaluate the cost of insects throughout the supply chain. The purpose of the tool is to optimize the logistics and identify segments of the supply chain that may require further development.

Feed/Food safety will focus on experimental studies and the identification of key hazards. A hazard characterization of relevant by-products will be determined along with the identification of critical control points for mealworm production. Activities on safety will focus on the obtained mealworm products depending on the used feeding substrates and processing method(s). Hazard characterization of relevant "grey zone" substrates - identified based on the availability, magnitude and cost - will be conducted to provide a foundation for assessing the possible contamination risks in mealworms produced on such substrates. The most relevant identified hazards will be tested in experimental production of mealworms under controlled conditions in order to investigate the fate of each hazard (i.e. occurrence, persistence and/or accumulation) in mealworm products, including the effect of different processing steps. The focus will be on i) microbiological hazard that may have an adverse effect on insect health and/or food/feed safety and on ii) chemical hazards, especially residues of antimicrobials and disinfectants.

\section{Product Application}

Animal feed experiments are carried out using rats and pig models to assess and document the nutritional and health value of insects in animal feed, and specifically the protein digestibility also applicable to human nutrition. Poultry feeding experiments are also carried out. The insects to be 
assessed are Tenebrio molitor, Alphitobius diaperinus, Hermetia illucens and likely Acheta domesticus.

The first animal trial, which is currently being analysed, involved eight diets containing $A$. diaperinus subdued to different treatment techniques (processing methods); heat-based drying, vacuum drying, acid hydrolysis, addition of enzymes, extrusion, freeze-drying and de-fatting, and one diet with freeze-dried T. molitor fed to rats in metabolism cages with collection of faeces and urine. Preliminary results are shown in Figure 1 and indicate high digestibility of both the freeze-dried $T$. molitor and $A$. diaperinus, but with slightly higher digestibility and nitrogen utilization of $A$. diaperinus than T. molitor. The protein digestibility-corrected amino acid score, PDCAAS (data not shown) was also higher for $A$. diaperinus.

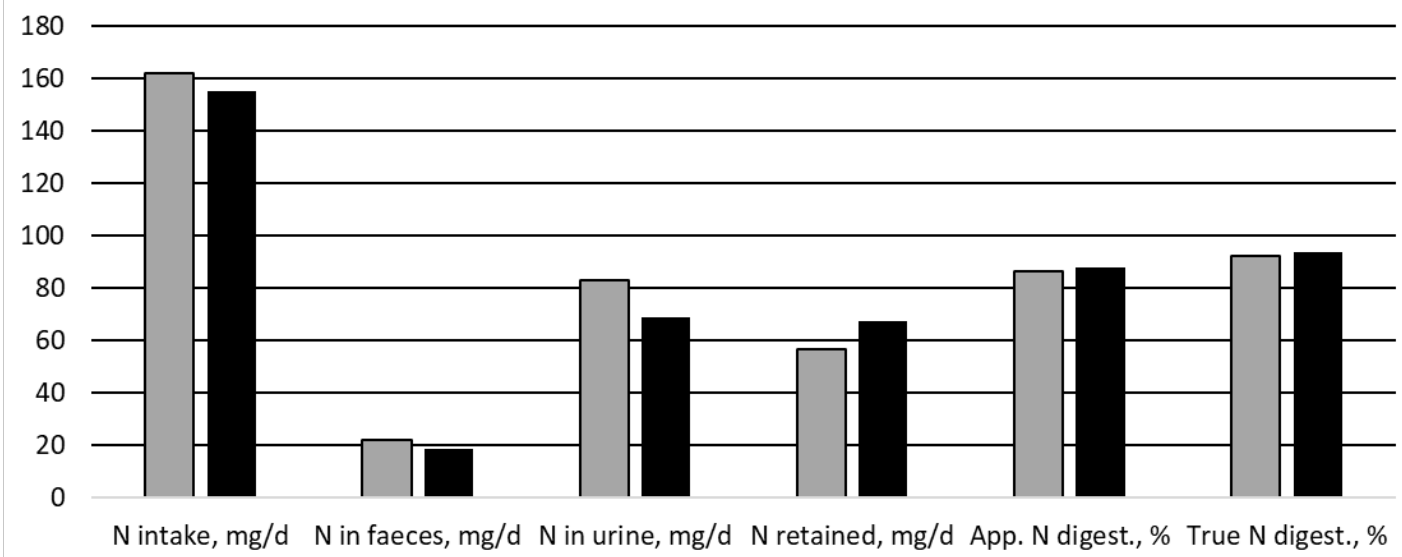

Figure 1. Nitrogen intake, output in faeces and urine $(\mathrm{mg} / \mathrm{d})$, retained and apparent (App.) and true nitrogen digestibility in rats fed freeze-dried Tenebrio molitor (grey bars) or Alphitobius diaperinus (black bars).

Results from the rat study will be used to design a protein evaluation study of $T$. molitor, $A$. diaperinus, $H$. illucens and $A$. domesticus fed to ileum cannulated pigs using the DIAAS method (FAO, 2013), which will provide data on digestibility coefficients and a basis for assessment of insects for human nutrition. Moreover, the data from the DIAAS study will provide the basis for formulating diets in a second pig experiment that will evaluate the effects of $T$. molitor, $A$. diaperinus and $H$. illucens on pig performance and health. Newly weaned piglets housed individually will be fed diets containing the insects and will be evaluated by growth performance parameters compared to a control diet. The $E$. coli level in intestinal content will be determined to investigate whether mealworms, or other species to be included, have an antimicrobial effect against $E$. coli 
Finally, an experiment on broiler chickens will assess growth performance when using T. molitor, $A$. diaperinus and $H$. illucens in the starter feed.

Food application activities focus on the functionality and nutritional value of mealworms for humans. Different types of treated insect-meal products will be tested in selected products and recipes; initially in baked goods, but also in other food applications. This will be supplemented by sensory assessment and screening of functional properties of the insect-meal. The animal studies conducted under the feed application work on protein digestibility are applicable to evaluate the nutritional value of mealworms also in humans based on the DIAAS method. The DIAAS assessment of protein quality based on a pig model is recommended by FAO to be valid to evaluate the protein quality for humans (Lee et al., 2016). In addition, the UCPH facilitate an MSc-course 'Thematic course in Food Innovation and Health', where students will be involved in ideation and execution of food with insects as a substantial ingredient involving stakeholders from the Danish food industry.

\section{Final remarks}

inVALUABLE has focus on the R\&D demand for scaling up production and assessing the application potential of mealworm (T. molitor); one of the edible insect species with high potential particularly in the food sector. In our opinion, it is important to keep focus on building know-how with individual insect species (e.g. T. molitor and H. illucens) in ongoing and future research and development projects. The rational being that to achieve maximum value proposition for the insect industry and society, we need to drive focused innovation that specifically can improve production at a species specific level; i.e. farming mealworms is as unique as farming Black Soldier Fly (BSF) or poultry or pigs. Moreover, differentiation of unique products for food based on the particular insect species in question is likewise key - just as we have unique applications for vertebrate livestock. As highlighted throughout this paper, our focus is during the duration of inVALUABLE to drive value chain innovation for mealworms.

In Denmark, there is a well-established tradition for corporation in the farming sector, organized in different guilds such as e.g. dairy and pig production. The Danish traditions and competences from cost-effective animal production can be a great support to achieve the aims of inVALUABLE, and make the insect value chain a successful new agri-business in Denmark and beyond. The inVALUABLE consortium is reaching out to external stakeholders to build collaborations in areas of common interest. Such external collaboration is ongoing with, e.g.: Proti-Farm (www.protifarm.com) regarding food application activities; Danish Insect Network 
(www.inbiom.dk/inbiom/netvaerk/dansk-insekt-netvaerk) and IPIFF (ipiff.org) regarding stakeholder relations throughout the value chain; regulatory dialogue with the Danish Veterinary and Food Authorities (www.dvfa.dk); and the Municipality of Copenhagen (www. international.kk.dk) regarding dissemination such as an annual edible insect festival, Copenhagen Bug Fest, which was launched in 2017 (www.copenhagenbugfest.dk).

Together with other large European R\&D initiatives, trade associations and networks, inVALUABLE is expected to have a large impact on shaping the growing insect industry in Denmark and globally.

Project updates will be available on most recent developments on inVALUABLE.dk

\section{References}

Berggreen, I. E., Offenberg, J., Calis, M., Heckmann L.-H, in press. Impact of density, reproduction period and age on fecundity of the yellow mealworm Tenebrio molitor (Coleoptera: Tenebrionidae), Journal of Insects as Feed and Food.

Bjørge, J. D., Overgaard, J., Malte, H., Gianotten, N., Heckmann, L.-H., in press. Role of temperature on growth and metabolic rate in the tenebrionid beetles Alphitobius diaperinus and Tenebrio molitor. Journal of Insect Physiology.

EFSA Scientific Committee, 2015. Risk profile related to production and consumption of insects as food and feed., 2015. EFSA Journal, 13(10), 4257. doi:10.2903/j.efsa.2015.4257

Eilenberg, J., Gasque, S.N., Ros, V.I.D., 2017. Natural enemies in insect production systems. In Van Huis, A, \& Tomberlin, J.K. (eds): Insects as Food and Feed from production to Consumption. Wageningen Academic Publishers, The Netherlands, 201-223.

Eilenberg, J., Jensen, A. B., Hajek, A. E.,2017. Prevention and Management of Diseases in Terrestrial Invertebrates. In Ecology of Invertebrate Diseases (pp. 495-526). Chichester, UK: John Wiley \& Sons, Ltd. doi:10.1002/9781119256106.ch14

Eilenberg, J., Vlak, J. M., Nielsen-LeRoux, C., Cappellozza, S., Jensen, A. B., 2015. Diseases in insects produced for food and feed. Journal of Insects as Food and Feed. doi:10.3920/JIFF2014.0022

FAO, 2013. Dietary protein quality evaluation in human nutrition Report of an FAO Expert Consultation. Retrieved from http://www.fao.org/ag/humannutrition/3597802317b979a686a57aa4593304ffc17f06.pdf

Halloran, A., Hanboonsong, Y., Roos, N., Bruun, S., 2017. Life cycle assessment of cricket farming in north-eastern Thailand. Journal of Cleaner Production. doi:10.1016/j.jclepro.2017.04.017

Heckmann, L. H., Andersen, J. L., Gianotten, N., Calis, M., Fischer, C. H., Calis, H. Sustainable Mealworm Production for Feed and Food. Book chapter, in press, Springer.

Homann, A. M., Ayieko, M. A., Konyole, S. O., Roos, N., 2017. Acceptability of biscuits containing $10 \%$ cricket ( Acheta domesticus ) compared to milk biscuits among 5-10-year-old Kenyan schoolchildren. Journal of Insects as Food and Feed, 3(2), 95-103. doi:10.3920/JIFF2016.0054 
Huis, A., Van Itterbeeck, J., Van Klunder, H., Mertens, E., Halloran, A., Muir, G., Vantomme, P., 2013. Edible insects: future prospects for food and feed security. FAO report 171. Retrieved from http://www.fao.org/docrep/018/i3253e/i3253e.pdf

Józefiak, A., Engberg, R., 2017. Insect proteins as a potential source of antimicrobial peptides in livestock production. A review. Journal of Animal and Feed Sciences, 26(2), 87-99. doi:10.22358/jafs/69998/2017

Kinyuru, J. N., Konyole, S. O., Roos, N., Onyango, C. A., Owino, V. O., Owuor, B. O., Kenji, G., 2013. Nutrient composition of four species of winged termites consumed in western Kenya. Journal of Food Composition and Analysis, 30(2), 120-124. doi:10.1016/J.JFCA.2013.02.008

Lee, W. T., Weisell, R., Albert, J., Tome, D., Kurpad, A. V., Uauy, R., 2016. Research Approaches and Methods for Evaluating the Protein Quality of Human Foods Proposed by an FAO Expert Working Group in 2014. Journal of Nutrition, 146(5), 929-932. doi:10.3945/jn.115.222109

Nordentoft, S., Fischer, C., Bjerrum, L., Heckmann, L. H., Hald, B., 2017. Reduction of Escherichia coli, Salmonella Enteritidis and Campylobacter jejuni in poultry manure by rearing of Musca domestica fly larvae. Journal of Insects as Food and Feed, 3(32), 145-153. doi:10.3920/JIFF2016.0058 